\title{
A PRECISE AND RAPID ANALYTICAL PROCEDURE FOR ALKALINITY DETERMINATION
}

FIZ F. PEREZ and F. FRAGA

Instituto de Investigacions Mariñas (CSIC), Peirao de Bouzas, 36208-Vigo (Spain)

\begin{abstract}
Perez, F.F. and Fraga, F., 1987. A precise and rapid analytical procedure for alkalinity determination. Mar. Chem., 21: 169-182.

A potentiometric analytical method is proposed for the determination of the alkalinity of seawater. The precision is $0.1 \%$ and each determination takes $3 \mathrm{~min}$. The technique is very easy to use, even on board ship since it is carried out in open flasks. A polynomial equation is also proposed which greatly simplifies the theoretical expression.
\end{abstract}

\section{INTRODUCTION}

Many marine scientists have considered the specific alkalinity as a constant chemical parameter in oceanic water. When glass electrodes for potentiometric measurements appeared, they were used for alkalinity measurements using techniques such as the Gran Plot (Gran, 1952). These procedures clearly showed slight variations in the specific alkalinity in the oceans of the world.

A precise method is interesting for two reasons: firstly, alkalinity would be useful for distinguishing water masses, mainly in the surface water, where it could replace temperature as a conservative parameter (Perez et al., 1986). Secondly, together with $\mathrm{pH}$, it could be related with other nutrients (total nitrogen, phosphate and oxygen) for studying the processes of sedimentation-oxidation of organic matter in mixing water masses. The method must also be easy to carry out at the same time as the nutrient salts are analysed on board ship and simple enough for workers not specialised in the carbon system. 
Alkalinity, expressed as equivalents per kilogram of seawater, does not depend on temperature and pressure. A variety of procedures has been used including the classical titration with an indicator proposed by Gripenberg (1936), and the 'method of $\mathrm{pH}$ (Anderson and Robinson, 1946) using a single point potentiometric titration, which was later modified by Culberson et al. (1970).

The potentiometric titration methods (Dyrssen, 1965; Dyrssen and Sillen, 1967) based on the Gran Plot reached a great precision $(0.17 \%$ in alkalinity determinations or $0.68 \%$ in total carbon determinations (Edmond, 1970). A more sophisticated method, which takes into account the prevailing reactions, was used by Hansson and Jagner (1973). They evaluated the equivalence points by a modified Gran Plot. If the dissociation constants of minor species which contribute to alkalinity are known, it is possible to obtain a complete theoretical expression of the potentiometric titration curve (Dickson, 1981; Johansson and Wedborg, 1982), and fitting the non-linear experimental curve to the theoretical expression it is possible to accurately evaluate alkalinity and total carbonate $(0.08 \%$ and $0.20 \%$, respectively).

All the potentiometric methods require that the titration be carried out in a closed system, since it takes at least $15 \mathrm{~min}$ to complete. When planning an oceanographic cruise it must be remembered that the time of analysis on board must be as short as possible and that this time should be similar for the different parameters to be determined, to optimise the amount of data obtained. Owing to biological activity the sample may not be stored longer than one day. Thus, it is necessary to find less sophisticated and more rapid methods. Non-linear methods have not been used in oceanographic cruises. On the contrary the linearised Gran Plot technique has been used with an automatic titrator. This method has been applied during some cruises (Almgren et al., 1977; Takahashi et al., 1981).

\section{METHOD}

The method proposed here is a modification of the ' $\mathrm{pH}$ method' consisting of a titration of the sample $\left(250 \mathrm{~cm}^{3}\right)$ to a final (NBS) $\mathrm{pH}$ close to 4.44 . The titration is carried out in an open flask (with the area of the interface as small as possible, usually $<8 \mathrm{~cm}^{2}$ ). The time of titration is about $3 \mathrm{~min}$, so that, practically, there is no loss of COs. A series of 
samples is also taken for $\mathrm{pH}$ measurements before and independently of the titration. On the molinity scale, the alkalinity is given by

$\mathrm{A}=2 \cdot \mathrm{C}_{\mathrm{Co}_{3}}+\mathrm{C}_{\mathrm{Hco}_{3}}+\mathrm{C}_{\mathrm{B}(\mathrm{OH})_{4}}+\mathrm{C}^{\mathrm{T}} \mathrm{OH}^{-} \mathrm{C}_{\mathrm{H}}^{\mathrm{T}}$

and taking into account the carbonic acid, boric acid and water equilibria, the following expression (Skirrow, 1975) can be written

$\mathrm{C}_{\mathrm{T}}=(\mathrm{A}+\mathrm{D}) \cdot \mathrm{E}$

where $\mathrm{D}$ and $\mathrm{E}$ are the following expressions

$\mathrm{D}=\frac{a_{H}^{\prime}}{f^{T}{ }_{H}}-\frac{B_{T} \cdot K_{B}^{\prime}}{K_{B}^{\prime}+a_{H}^{\prime}}-\frac{K_{W} \cdot f_{H}{ }^{T}}{a_{H}^{\prime}}$

and

$\mathrm{E}=\frac{1+\left(a_{H}^{\prime} / K_{]}^{\prime}\right)+\left(K_{2}^{\prime} / a_{H}^{\prime}\right)}{1+\left(2 K_{2}^{\prime} / a_{H}^{\prime}\right)}$

and, as there is no loss of COs, the following expression is obtained by equilization of the initial and final values of $\mathrm{C}_{\mathrm{T}}$.

$\mathrm{A}=\mathrm{N}_{\mathrm{HCI}} \cdot \mathrm{V}_{\mathrm{HCI}} / \mathrm{W}+\frac{D_{f} \cdot E_{f} \cdot\left(1+V_{H C I} / W\right)-E_{i} \cdot\left(D_{i}+N_{H C I} \cdot V_{H C I} / W\right)}{E_{i}-E_{j}}(5)$

where $i$ and $f$ are the initial and final values of titration, $\mathrm{V}_{\mathrm{HCI}}$ and $\mathrm{N}_{\mathrm{HCI}}$ are, respectively, the added volume and molarity $(0.1 \mathrm{M})$ of hydrochloric acid and Wis the mass of the sample (on board a Knudsen pipette is used to measure the volume $\left( \pm 0.02 \mathrm{~cm}^{3}\right)$ and the mass is then calculated as a function of salinity and temperature).

The salinity and temperature of the sample to be titrated must be known to determine the dissociation constants and $\mathrm{B}_{\mathrm{T}}$. Constants $\mathrm{K}^{\prime}{ }_{1}$ and $\mathrm{K}_{2}{ }_{2}$ are given by Mehrbach et al. (1973), K' ${ }_{\mathrm{B}}$ by Lyman (1956) and $\mathrm{K}_{\mathrm{w}}$ by Dickson and Riley (1979). Pérez and Fraga (1987) give an expression to calculate $\mathrm{f}_{\mathrm{H}}^{\mathrm{T}}$ obtained from the determinations of Mehrbach et al. (1973), and they discuss the use of $f^{T}{ }_{H}$ to evaluate the systematic error in $\mathrm{pH}$ determination in seawater.

Calculations are rapid and easy to carry out with a microcomputer. The experimental procedure of this method is also rapid and easy.

\section{MATERIAL}


Sodium tetraborate decahydrate (Borax, $\mathrm{Na}_{2} \mathrm{~B}_{4} \mathrm{OT}_{7} 10 \mathrm{H}_{2} 0$, Merck p.a.) was used as standard. It was in isopiestic equilibrium with a solution saturated with both sodium chloride and sucrose.

The hydrochloric acid $(\approx 0.1 \mathrm{M})$ was potentiometrically titrated vs. borax to a final $\mathrm{pH}$ of $5.3 \pm 0.05$.

$\mathrm{pH}$ measurements were carried out with a combined glass electrode (Metrohm E-121) with $\mathrm{Ag} / \mathrm{AgC1}(\mathrm{KC} 13 \mathrm{M})$ as reference. To standardize the electrode, we used a phosphate buffer (NBS-7.413), assuming the theoretical slope. Determinations of $\mathrm{f}_{\mathrm{H}}^{\mathrm{T}}$ were carried out to evaluate the systematic errors in the $\mathrm{pH}$ measurements. These errors are due to variations in the residual liquid-junction potential.

A pH meter Metrohm E-510 was used with an automatic burette (Metrohm 415) and an impulsomat (Metrohm E-473) for the potentiometric titrations.

\section{DIFFUSION OF CARBON DIOXIDE DURING THE TITRATION}

The $\mathrm{CO}_{2(\mathrm{~g})}$ interchange is kinetically controlled by diffusion through the interface since the speed of dehydration of $\mathrm{H}_{2} \mathrm{CO}_{3}$ is greater than the rate of diffusion. The rate of diffusion of the gas across the interface is given by

$\mathrm{J}=\mathrm{K}_{\mathrm{d}} \cdot \Delta \mathrm{P}_{\mathrm{co}_{2}}$

where $K_{d}$ is the velocity constant of transference, with a value of $20 \cdot 10^{-6} \mathrm{~mol} . \mathrm{cm}^{-2} \mathrm{~min}^{-}$ ${ }^{1} \mathrm{~atm}^{-1}$ (Skirrow, 1975), $\Delta \mathrm{P}_{\mathrm{co} 2}$ is the difference in $\mathrm{CO}_{2}$ partial pressure between the two phases. This difference is calculated from the $\mathrm{CO}_{2}$ solubility in seawater (Weiss, 1974).

Usually seawater titrations are carried out in a beaker of $400 \mathrm{~cm}^{3}$ volume and an interface surface of $46 \mathrm{~cm}^{2}$ or, preferably, in a conical flask of $280 \mathrm{~cm}^{3}$ volume and an interface surface of $8 \mathrm{~cm}^{2}$. The titration consists of the following steps:

(1) $0.25 \mathrm{~min}$ to equilibrate the electrodes in the sample;

(2) $1-1.5$ rain to add $90 \%$ of the acid;

(3) $0.5 \mathrm{~min}$ to add the rest of the acid and pre-stabilisation of final $\mathrm{pH}$; and 
(4) $0.5 \mathrm{~min}$ to stabilize and read the final $\mathrm{pH}$. This latter interval is also used to fill the burette for the following determinations.

To evaluate, the loss of $\mathrm{CO}_{2}$, in a more logical way, we need to calculate the effective time the solution is subject to a fixed partial pressure. The $\mathrm{P}_{\mathrm{co2}}$ has a linear increase on adding $\mathrm{HC} 1$, in the second step. Thus, $\Delta \mathrm{P}_{\mathrm{co} 2}$ can be taken as the maximum value $(0.06$ atm) and the effective time, at most, equals a half of the time consumed in the second step, more of the time consumed in the third and fourth ones. The solutions will be then $1.75 \mathrm{~min}$ at a partial pressure of $0.06 \mathrm{~atm}$ approximately. Taking into account eq. 6

$$
\begin{aligned}
\Delta \mathrm{CT}= & -\mathrm{K}_{\mathrm{d}} \cdot\left(\Delta \mathrm{P}_{\mathrm{co} 2}\right)-\mathrm{S} \cdot \mathrm{t} \\
& =-0.020 \mathrm{mmol} \cdot \mathrm{atm}^{-1} \cdot \mathrm{min}^{-1} \cdot \mathrm{cm}^{-2} \cdot 0.06 \mathrm{~atm} \cdot 1.75 \mathrm{~min} \cdot 46 \mathrm{~cm}^{2} \\
& =-80.10^{6} \mathrm{~mol} \ldots . .4 \% \text { of } \mathrm{C}_{\mathrm{T}}
\end{aligned}
$$

which gives rise to a systematic error of $-0.11 \%$ in alkalinity. These systematic errors are calculated including in eq. 5 the loss of $\mathrm{C}_{\mathrm{T}}$ (if $4 \%$ of $\mathrm{C}_{\mathrm{T}}$ lost, $\mathrm{E}_{\mathrm{i}}$ changes to $0.96 \mathrm{E}_{\mathrm{i}}$ ). Using conical flasks this error would decrease to $0.02 \%$ because the interface is six times smaller.

To confirm these estimates of $\mathrm{C}_{\mathrm{T}}$ loss, two kinds of experiments were devised. In the first set of experiments, seawater was titrated with $\mathrm{HC} 1$ and the final solution was allowed to lose $\mathrm{CO}_{2}$ for some time while maintaining the $\mathrm{pH}$ constant by adding $\mathrm{HC} 1$ (experiments 1-5, Table I). In the second set of experiments $\mathrm{HC} 1$ was not added and the increase of $\mathrm{pH}$ was measured after some time (experiments 7-10, Table I). The alkalinity of the sample was determined from the data of the first step. The values of $\mathrm{C}_{\mathrm{T}}$ and $\mathrm{C}_{\mathrm{T}} \mathrm{T}$ are, respectively, the total inorganic carbon of the sample at the final point of titration $\left(\mathrm{pH}=\mathrm{pH}_{\mathrm{f}}\right)$ and after some time $\left(\mathrm{pH}=\mathrm{ph}_{\mathrm{f}}\right)$. They are calculated using eqs. 2-4 taking into account the alkalinity $\left(=\mathrm{A}-\mathrm{V}_{\mathrm{HCl}} \cdot \mathrm{N}_{\mathrm{HCl}} / \mathrm{W}\right)$ and $\mathrm{pH}$ at both points. When comparing losses of $\mathrm{CO}_{2}$ per unit time $\left(\Delta \mathrm{C}_{\mathrm{T}} / \mathrm{t}\right)$, a decrease directly influenced by a decrease of the interface area is observed and the losses are similar to those estimated from eq. $6\left(-45 \cdot 10{ }^{6} \mathrm{molkg}^{-1}\right.$ of $\left.\mathrm{C}_{\mathrm{T}} \mathrm{min}^{-1}\right)$. In fact, as some $\mathrm{CO}_{2}$ is lost, the partial pressure in the vicinity of the solution is greater than the atmospheric one. This can be clearly seen in experiment 10 (Table I). 
Thus the possible error introduced in the determination of alkalinity (eq. 5) by loss of $\mathrm{CO}_{2}$ during titration is $<0.05 \%$, if titrations are carried out with interface surfaces $<8$ $\mathrm{cm}^{2}$.

\section{REPRODUCIBILITY}

The mean error was estimated by carrying out repeated measurements of alkalinity on the sample that was stored in a plastic container of 251 volume. The electrode was standardized with NBS buffer 7.413 (normally once a day on board) and it remained in seawater for more than $30 \mathrm{~min}$ to obtain the best stabilization of the residual liquidjunction potential. When this time had elapsed the $\mathrm{pH}$ of the sample was measured and repeated titrations were carried out, as in practice.

After the system was considered stable, 23 detailed measurements were made as shown in Table II, obtaining a reproducibility of the method better than $0.1 \%$.

This same experiment was repeated 21 days later to test the reproducibility in time (electrode standardization). It is assumed that sample alkalinity does not vary since the volume is great enough and remains stored in a closed container. Table III shows that values of alkalinity and $\mathrm{pH}$ are perfectly' reproduced within the experimental errors.

\section{ACCURACY}

Five prior measurements of alkalinity in the same water sample were carried out both by the classical method (Gripenberg, 1936) modified to use a glass electrode, as well as by the new method proposed here, giving $2360 \pm 7$ and $2364 \pm 2 \mu \mathrm{mol} \mathrm{kg}^{-1}$, respectively. The classical method is troublesome for the following reasons: it is not so accurate, the time of titration is longer and it has, in addition, the inconvenience of having to boil the sample.

To confirm the method, we prepared different standard solutions similar to natural seawater. The preparation of synthetic water is inconvenient due to the presence of nutrients as impurities of major salts. This gives rise to seawater with an unstable carbonic system due to the possibility of photosynthesis. Besides this, it is easier to 
obtain natural seawater with very low nutrient concentrations. In these solutions the residual alkalinity must be known $\left(<50 \mu \mathrm{mol} \mathrm{kg}^{-1}\right)$ after being neutralized and free of $\mathrm{CO}_{2}$. This residual alkalinity is determined, either by measuring the $\mathrm{pH}(\mathrm{NBS})$ after seawater has reached the equilibrium at atmospheric $\mathrm{CO}_{2}$ pressure and then calculating the alkalinity through the equations of the carbonic system equilibrium (Skirrow, 1975), or by measuring the $\mathrm{pH}$ after further additions of $\mathrm{HC} 1$, with the alkalinity obtained as the intercept on the ordinate when the acid concentration of the sample vs. hydrogen ion activity $\left(\mathrm{a}^{\prime} \mathrm{H}\right)$ is plotted.

After the seawater was neutralized and free of $\mathrm{CO}_{2}$ and the alkalinity was known, we obtained some seawater standards with alkalinities similar to natural seawater by adding fixed amounts of $\mathrm{NaHCO}_{3}$ or $\mathrm{Na}_{2} \mathrm{CO}_{3}$. Some of these standards are somewhat unstable (24h) due to the possible precipitation of $\mathrm{CaCO}_{3}$.

Using seawaters with the following salinities and alkalinities:

SWI: $\mathrm{S}=34.5$ and $\mathrm{A}=33 \mu \mathrm{molkg}{ }^{-1}$

$\mathrm{SW} 2: \mathrm{S}=34.2$ and $\mathrm{A}=0.5 \mu \mathrm{mol} \mathrm{kg}{ }^{-1}$

SW3: $\mathrm{S}=35.2$ and $\mathrm{A}=2317.4 \mu \mathrm{molkg}^{-1}$

SW4: $\mathrm{S}=35.4$ and $\mathrm{A}=0.1 \mu \mathrm{molkg}^{-1}$

a series of standard solutions was prepared as follows:

(1) $0.37525 \mathrm{~g}$ of $\mathrm{NaHCO}_{3}+1026.08 \mathrm{~g}$ of SW1;

(2) $0.40780 \mathrm{~g}$ of $\mathrm{NaHCO}_{3}+2072.04 \mathrm{~g}$ of SW2;

(3) $0.38282 \mathrm{~g}$ of $\mathrm{NaHCO}_{3}+1010.28 \mathrm{~g}$ of SW2;

(4) $0.27067 \mathrm{~g}$ of $\mathrm{Na}_{2} \mathrm{CO}_{3}+2067.74 \mathrm{~g}$ of SW3;

(5) $0.21427 \mathrm{~g}$ of $\mathrm{NaHCO}_{3}+1040.2 \mathrm{~g}$ of SW3; and

(6) $0.19456 \mathrm{~g}$ of $\mathrm{Na}_{2} \mathrm{CO}_{3}+752.63 \mathrm{~g}$ of SW4 $+34.20 \mathrm{~g}$ of $\mathrm{HC} 1$.

The amount of pure $\mathrm{NaHCO}_{3}$ is calculated weighting the $\mathrm{Na}_{2} \mathrm{CO}_{3}$ resulting from heating to $520^{\circ} \mathrm{C}$.

Titrations carried out with these standards (Table IV) clearly show that the error of method is $<0.1 \%$. 


\section{SIMULATION OF ERROR IN THE CALCULATION OF ALKALINITY AND TOTAL INORGANIC CARBON}

It is necessary to know the experimental parameters most influencing alkalinity measurements. The results expressed in Table $\mathrm{V}$ are obtained by introducing the measurement error of each experimental parameter into the calculation processes (Eqs. $1-5)$.

The concentration of total inorganic carbon is calculated from alkalinity and initial $\mathrm{pH}$ of the sample. Thus, the experimental error in that concentration is greatly influenced by errors of the initial $\mathrm{pH}$ apart from that propagated by alkalinity (Table V). The table shows the influence of dissociation constants of carbonic and boric acid, water and the activity coefficient of hydrogen ions. The values shown in Table $\mathrm{V}$ are taken from UNESCO (1983). These determinations are affected by the same residual liquidjunction potential. To use these constants and to introduce no systematic error when measuring alkalinity and total inorganic carbon, the $\mathrm{pH}$ measurements must be affected by this residual liquid-junction potential.

Although uncertainties in $\mathrm{K}_{\mathrm{w}}$ and $\mathrm{K}^{\prime}{ }_{\mathrm{B}}$ do not influence the alkalinity, $\mathrm{K}_{\mathrm{B}}$ influences the determination of total inorganic carbon.

Other bases such as phosphate and silicate ions may also contribute to alkalinity in seawater. Phosphate is present in natural seawater, mainly as $\mathrm{HPO}_{4}\left(\mathrm{pK}_{1}=1.6, \mathrm{pK}_{3}=\right.$ 6.1 and $\mathrm{pK}_{3}=9.1$; Dickson and Riley, 1979) and its contribution is practically equivalent for equivalent to alkalinity, thus it does not introduce errors in the titrated alkalinity. On the other hand, the second and third dissociation constants are close to those of carbonic acid. The contribution to total carbonate, as calculated in eq. 2 is practically mole for mole. If the phosphate ion is not taken into account in these equations, a systematic (mathematical) error appears in total carbonate which equals the phosphate concentration. Since the silicate ion $\left(\mathrm{pK}_{1}=9.5\right)$ has a constant three times smaller than $\mathrm{K}_{2}{ }_{2}$, it does not significantly contribute to the alkalinity; the contribution to total carbonate being $1 / 12$ of the total silicate concentration at $\mathrm{pH} 8.4$ and $1 / 50$ at $\mathrm{pH}$ 7.8 . 


\section{POLYNOMIAL EQUATION}

Calculation of alkalinity from the experimental parameters requires the use of many equations; this is really tedious, although not difficult. The simplification of calculations for the following range of experimental parameters seems convenient:

(1) Initial pH 7.8-8.4.

(2) Final $\mathrm{pH} 4.0-4.6$. The $\mathrm{pH}_{\mathrm{f}}$ appears in this interval after addition of $94 \%$ of the equivalent volume of $\mathrm{HCI}$.

(3) Salinity 20-40.

(4) Specific alkalinity from 40 to $80 \mu \mathrm{mol} \mathrm{g}^{-1}$ of salt.

(5) Titration temperature $10-25^{\circ} \mathrm{C}$.

(6) HC1 molarity 0.07-0.13 M.

The alkalinity neutralized in the titration is $\mathrm{AN}=\mathrm{V}_{\mathrm{HCl}} \cdot \mathrm{N}_{\mathrm{HCl}} / \mathrm{W} \cdot 1 \mathrm{O}^{6}\left(\mu \mathrm{molkg}^{-1}\right)$

The system of equations (2-5), which also involves those equations that define the equilibrium constants, can be reduced to

$$
\begin{aligned}
\mathrm{A}=\mathrm{A}_{\mathrm{N}} & -15.5+0.52(\mathrm{~S}-30)+213.5\left(\mathrm{pH}_{\mathrm{f}}-4.4\right) \\
& +0.002276\left(\mathrm{~A}_{\mathrm{N}}-2000\right)+302.9\left(\mathrm{pH}_{\mathrm{f}}-4.4\right)^{3} \\
& +0.04310\left(\mathrm{pH}_{\mathrm{f}}-4.4\right)\left(\mathrm{A}_{\mathrm{N}}-2000\right)(7)
\end{aligned}
$$

for the intervals mentioned above, through a minimization process by least squares. If the titration is carried out in a temperature range of $15-22^{\circ} \mathrm{C}$, this equation gives the alkalinity with an error of $\pm 3 \mu \mathrm{mol} \mathrm{kg}^{-1}$.

Isolines of error using the proposed eq. 7 vs. the theoretical one, are represented in Figs. 1 and 2 . Almost the whole error area $( \pm 0.1 \%)$ covers the zone of basic variables used in the calculations.

This equation greatly simplifies the alkalinity titrations. When the titrations are run at a temperature of about $20^{\circ} \mathrm{C}$ in a flask with a surface of interface $<8 \mathrm{~cm}^{2}$ and HCI of a known molarity is added (not more than 2 rain must be used) until $\mathrm{pH}_{\mathrm{f}}$ within the range 4.0-4.6 is reached, the neutralized alkalinity is calculated, and using data of salinity and $\mathrm{pH}_{\mathrm{f}}$, we obtain the alkalinity of the sample through eq. 7 . 


\section{DISCUSSION}

This method is good for the analysis of a large number of samples, since it is much more rapid than any of the methods described in the bibliography. An exception may be the potentiometric method described with linear fitting proposed by Dickson (1981), which is more accurate and precise $(0.08 \%$ compared with $0.1 \%$, Johansson and Wedborg, 1982). However, the time used is five times longer and the standardization more sophisticated. The potentiometric Gran Plot method, which was proposed by Edmond (1970), presents a similar precision (0.17\%) but the time used is also longer (15-20 min).

The method described here is an improvement on that proposed by Culberson et al. (1970), which improves, at the same time, the method of Anderson and Robinson (1946). It is simpler and more precise due to suppression of the step which eliminates the $\mathrm{CO}_{2}$ in the final $\mathrm{pH}$ measurement. Equation 5 may be simplified in an approximate way for comparison with the expression given by Culberson et al.

$$
\mathrm{A}=\mathrm{N}_{\mathrm{HCl}} \cdot \mathrm{V}_{\mathrm{HCl}} / \mathrm{W}+\mathrm{a}^{\prime}{ }_{\mathrm{H}}\left(1+\mathrm{V}_{\mathrm{HCl}} / \mathrm{W}\right) / \mathrm{f}^{\mathrm{T}}{ }_{\mathrm{H}}+\mathrm{K}^{\prime}{ }_{1} \cdot\left(\frac{\left(1+V_{H C I} / W\right)}{f^{T}{ }_{H}}-\frac{C_{T}}{a_{{ }_{H}}^{\prime}}\right)
$$

The last term does not appear in the conventional $\mathrm{pH}$-method, because in its final conditions the $\mathrm{pH}_{\mathrm{f}}$ is lower $(\approx 3)$ or $\mathrm{CO}_{2}$ is eliminated.

The method proposed here was applied to 3000 samples collected off the coasts of Galicia and Portugal during the cruises "Galicia-V", "Galicia-VI", 'Galicia-VII" and "Galicia-VIII" and good results were obtained (Fraga et al., 1985). In addition, it enables one to study mixing of water masses, using the type values of alkalinity for different water masses. In a first approach an error of $0.15 \%$ was obtained for water bodies off Galician and Portuguese coasts.

\section{ACKNOWLEDGEMENTS}

This work was supported by the project of Comision Asesora de Investigacion Cientifica y Tecnica number 0019-81C03-00. We thank C. Mouriño for translation of the text into English. Dr. Whitfield and anonymous reviewers have criticised the work and corrected the text, for which we thank them. 


\section{LIST OF SYMBOLS}

Concentration units are given in moles per kilogram of seawater $\left(\mathrm{mol} \mathrm{kg}^{-1}\right.$, molinity scale, Whitfield and Jagner, 1981), which do not depend on pressure and temperature.

A total alkalinity in $\mathrm{mol} \mathrm{kg}^{-1}$ (UNESCO, 1985)

$\mathrm{A}_{\mathrm{sp}} \quad$ specific alkalinity $(\mathrm{A} / \mathrm{S})$, in $\mu \mathrm{mol} \mathrm{g}^{-1}$ of salt

$\mathrm{A}_{\mathrm{N}} \quad$ neutralized alkalinity in $\mu \mathrm{mol} \mathrm{kg}{ }^{-1}$ in the titration $\left(=\mathrm{V}_{\mathrm{HCl}} \cdot \mathrm{N}_{\mathrm{HCl}} / \mathrm{W}\right)$

$\mathrm{A}^{\prime}{ }_{\mathrm{H}}$ apparent activity of hydrogen ions, $\mathrm{a}_{\mathrm{H}}(\mathrm{NBS})$

$\mathrm{B}_{\mathrm{T}} \quad$ total borate

$\mathrm{C}_{\mathrm{T}}$ total inorganic carbon

$\mathrm{f}_{\mathrm{H}}^{\mathrm{T}} \quad$ apparent activity coefficient of total hydrogen ions

$\mathrm{K}_{1}{ }_{1}, \mathrm{~K}_{2} \quad$ apparent constants of carbonic acid

$\mathrm{K}_{\mathrm{B}} \quad$ apparent constant of boric acid

$\mathrm{K}_{\mathrm{W}} \quad$ stoichiometric constant of water

$\mathrm{N}_{\mathrm{HCI}}$ molarity of hydrochloric acid

$\mathrm{pH}(\mathrm{NBS}) \quad$ scale of apparent activity of hydrogen ions

$\mathrm{pH}_{\mathrm{i}} \quad \mathrm{pH}(\mathrm{NBS})$ of the sample

$\mathrm{pH}_{\mathrm{f}} \quad \mathrm{pH}(\mathrm{NBS})$ of the sample at the final point of titration

S salinity

$\mathrm{t}$ temperature in ${ }^{\circ} \mathrm{C}$

$\mathrm{V}_{\mathrm{HCI}}$ volume of hydrochloric acid in $\mathrm{cm}^{3}$

W mass of the seawater sample

\section{REFERENCES}

Almgren, T., Dyrssen, D. and Stramberg, M., 1977. Computerized high-precision titrations of some major constituents of seawater on board the R.V. Dmitry Mendeleev. Deep-sea Res., 24: 34 364.

Anderson, D.H. and Robinson, R.J., 1946. Rapid electrometric determination of the alkalinity of seawater. Ind. Eng. Chem. Anal. Edn., 18: 767-769.

Culberson, C.H., Pytkowicz, R.M. and Hawley, J.E., 1970. Seawater alkalinity determination by the $\mathrm{pH}$ method. J. Mar. Res., 28: 15-21. 
Dickson, A.G., 1981. An exact definition of total alkalinity and a procedure for the estimation of alkalinity and total inorganic carbon from titration data. Deep-sea Res., 28A (6): 6094; 23.

Dickson, A.G. and Riley, J.P., 1979. The estimation of acid dissociation constants in seawater media from potentiometric titrations with strong base. I. The ionic product of water K w. Mar Chem., 7: 89-99.

Dickson, A.G. and Riley, J.P., 1979 b. The estimation of acid dissociation constants in seawater media from potentiometric titrations with strong base. II. The dissociation of phosphoric acid. Mar. Chem., 7:101-109.

Dyrssen, D., 1965. A Gran titration of seawater on board Sagitta. Acta Chem. Scand., 19: 1265.

Dyrssen, D. and Sillen, L.G., 1967. Alkalinity and total carbonate in seawater. A plea for P T independent data. Tellus, 19: 11-121.

Edmond, J.M., 1970. High precision determination of titration alkalinity and total carbon dioxide content of seawater by potentiometric titration. Deep-sea Res., 77: 737-750.

Fraga, F., Mouriño, C., Perez, F.F. and Rios, A.F., 1985. Campañas "Galicia-V', "Galicia-VI", "Galicia-VII" and "Galicia-VIII", Datos Basicos. Datos informativos del Inst. Inv. Pesq. Nos. 10, 11, 12 and 13.

Gran, G., 1952. Determination of the equivalence point in potentiometric titrations. Part II. The analyst, 77: 661-71.

Gripenberg, S., 1936. Comm. 108 V. Hydrolog. Conf. Baltic States. Helsinfirs, pp. 15. Hansson, I. and Jagner, D. 1973. Evaluation of the accuracy of Gran Plots by means of computer calculations. Applications to the potentiometric titration of the total alkalinity and carbonate content in seawater. Anal. Chim. Acta, 65: 36-373.

Johansson, O. and Wedborg, M., 1982. On the evaluation of potentiometric titrations of seawater with hydrochloric acid. Oceanol. Acta, 5: 209-218.

Lyman, J., 1956. Buffer Mechanism of Seawater. Ph. D. Thesis, University of California, Los Angeles.

Mehrbach, C., Culberson, C.H., Hawley, J.E. and Pytkowicz, R.M., 1973.

Measurements of the apparent dissociation constants of carbonic acid in seawater at atmospheric pressure. Limnol. Oceanogr., 18: 897-907.

Perez, F.F., Estrada, M. and Salat, J., 1986. Sistema del carbónico, oxígeno y nutrientes en el Mediterráneo occidental. Inv. Pesq., 50: 33-351. 
Perez, F.F. and Fraga, F., 1987. The pH measurements in seawater on NBS scale. Mar. Chem, in press

Skirrow, G., 1975. The Dissolved Gases - Carbon Dioxide. In: J.R. Riley and G.

Skirrow (Editors), Chemical Oceanography 1-81. Academic Press, II edn., vol. 2, New York.

Takahaski, T., Broeker, W.S. and Bainbridge, A.E., 1981. The alkalinity and total Carbon Dioxide Concentration in the World Oceans. In. B. Bolin (Editor), Carbon Cycle Modelling Scope 16. J Wiley, New York, pp. 271-286.

UNESCO, 1983. Technical papers in marine science. Carbon dioxide sub-group of the joint panel on oceanographic tables and standard. No. 42.

UNESCO, 1985. Technical papers in marine science, The International System of Units (SI) in Oceanography. No. 45.

Weiss, R.F., 1974. Carbon dioxide in water and seawater: the solubility of a non-ideal gas. Mar Chem., 2: 203-215.

Whitfield, M. and Jagner, D., 1981. Seawater as an electrochemical medium. 3-66. In: M. Whitfield and D. Jagner (Editors), Marine Electrochemistry. J. Wiley, New York, pp. 529 


\section{TABLE I}

The loss of total inorganic carbon $\left(\mathrm{C}_{\mathrm{T}}\right)$ as $\mathrm{CO}_{2(\mathrm{~g})}$ through the interface after reaching the end point of titration

\begin{tabular}{|c|c|c|c|c|c|c|c|c|c|c|c|c|c|}
\hline \multirow[t]{3}{*}{ Exp. } & \multicolumn{5}{|c|}{ Titration data } & \multicolumn{2}{|c|}{ Titration results of } & \multicolumn{4}{|l|}{ After titration } & \multirow{3}{*}{$\begin{array}{l}\text { Loss } \\
\text { per } \\
\min \\
\left(\Delta \mathrm{C}_{\mathrm{T}} \min ^{-1}\right)\end{array}$} & \multirow{3}{*}{$\begin{array}{l}\text { Area } \\
\left(\mathrm{cm}^{2}\right)\end{array}$} \\
\hline & \multirow{2}{*}{$\begin{array}{l}\text { Initial } \\
\mathrm{S}\end{array}$} & \multirow[b]{2}{*}{$\mathrm{t}$} & \multirow[b]{2}{*}{$\mathrm{pH}_{15}$} & \multirow{2}{*}{$\begin{array}{l}\text { Final } \\
\mathrm{pH}_{\mathrm{f}}\end{array}$} & \multirow[b]{2}{*}{$\mathrm{V}_{\mathrm{HCI}}$} & \multirow[t]{2}{*}{$\mathrm{A}$} & \multirow[t]{2}{*}{$\mathrm{C}_{\mathrm{T}}$} & \multicolumn{2}{|l|}{ Experimental } & \multirow[b]{2}{*}{$\mathrm{pH}_{\mathrm{f}}^{\prime}$} & \multirow{2}{*}{$\begin{array}{l}\text { Calculated } \\
\mathrm{C}^{\prime}{ }_{\mathrm{T}}\end{array}$} & & \\
\hline & & & & & & & & Time & $\mathrm{V}^{\prime}{ }_{\mathrm{HCI}}$ & & & & \\
\hline 1 & 29.01 & 18.3 & 8.233 & 4.468 & 4.851 & 1936 & 1696 & 7.6 & 4.867 & 4.468 & 1409 & 38 & 46 \\
\hline 2 & 32.67 & 18.3 & 8.233 & 4.470 & 5.396 & 2161 & 1870 & 30 & 5.451 & 4.470 & 1010 & 28 & 46 \\
\hline 3 & 34.77 & 18.3 & 8.192 & 4.470 & 5.706 & 2290 & 1989 & 9 & 5.723 & 4.470 & 1696 & 33 & 46 \\
\hline 4 & 35.30 & 18.5 & 7.818 & 4.467 & 5.706 & 2295 & 2149 & 16 & 5.737 & 4.467 & 1677 & 30 & 46 \\
\hline 5 & 35.41 & 18.4 & 7.818 & 4.424 & 5.670 & 2269 & 2125 & 16 & 5.696 & 4.424 & 1659 & 30 & 46 \\
\hline 6 & 35.41 & 18.4 & 7.818 & 4.340 & 5.734 & 2275 & 2130 & 21 & 5.734 & 4.378 & 1681 & 23 & 46 \\
\hline 7 & 35.41 & 18.4 & 7.818 & 4.195 & 5.837 & 2280 & 2133 & 18 & 5.837 & 4.202 & 1961 & 9.6 & 8 \\
\hline 8 & 35.41 & 18.4 & 7.818 & 4.427 & 5.694 & 2274 & 2134 & 16 & 5.694 & 4.432 & 2041 & 5.8 & 8 \\
\hline 9 & 35.41 & 18.4 & 7.818 & 4.420 & 5.677 & 2271 & 2126 & 14 & 5.677 & 4.428 & 2004 & 8.7 & 8 \\
\hline \multirow[t]{3}{*}{10} & 35.41 & 18.4 & 7.818 & 4.422 & 5.728 & 2272 & 2127 & 12 & 5.728 & 4.429 & 2005 & 9.3 & 8 \\
\hline & & & & & & & & 17 & 5.728 & 4.432 & 1988 & 8.2 & 8 \\
\hline & & & & & & & & 28 & 5.728 & 4.438 & 1935 & 6.9 & 8 \\
\hline
\end{tabular}


$\mathrm{C}_{\mathrm{T}}$ (in $\mu \mathrm{mol} \mathrm{kg}{ }^{-1}$ ) is calculated from the alkalinity (in $\mu \mathrm{mol} \mathrm{kg}^{-1}$ ) and $\mathrm{pH}_{\mathrm{f}}$ of the sample. In experiments 1 to 5 more $\mathrm{V}_{\mathrm{HCI}}$ (in ml) is added to keep $\mathrm{pH}$ constant $\left(=\mathrm{pH}_{\mathrm{f}}\right)$. In experiments 6-10 the $\mathrm{pH}$ changes due to loss of $\mathrm{CO}_{2} . \mathrm{C}^{\prime}{ }_{\mathrm{T}}$ is the carbon present after some time (in min) of the titration and it is calculated through the $\mathrm{pH}^{\prime}{ }_{\mathrm{f}}$ and the alkalinity at that moment of titration. $\left(\mathrm{N}_{\mathrm{HCl}} / \mathrm{W}\right)=400 \mu \mathrm{mol} \mathrm{kg}^{-1} \mathrm{ml}^{-1}$. 
TABLE II

Experiments carried out to determine the reproducibility of the proposed method

\begin{tabular}{|l|l|l|l|}
\hline Exp. & $\mathrm{pH}_{\mathrm{f}}$ & $\mathrm{V}_{\mathrm{HCI}}$ & $\mathrm{A}$ \\
\hline 1 & 4.440 & 4.833 & 2284.4 \\
\hline 2 & 4.442 & 4.830 & $2283 \mathrm{~A}$ \\
\hline 3 & 4.431 & 4.839 & 2284.8 \\
\hline 4 & 4.443 & 4.832 & 2284.4 \\
\hline 5 & 4.453 & 4.825 & 2283.7 \\
\hline 6 & 4.428 & 4.837 & 2283.1 \\
\hline 7 & 4.450 & 4.829 & 2284.9 \\
\hline 8 & 4.450 & 4.826 & 2283.2 \\
\hline 9 & 4.444 & 4.827 & 2282.2 \\
\hline 10 & 4.128 & 5.002 & 2282.8 \\
\hline 11 & 4.441 & 4.830 & 2282.9 \\
\hline 12 & 4.433 & 4.840 & 2285.8 \\
\hline 13 & 4.458 & 4.824 & 2284.1 \\
\hline 14 & 4.442 & 4.832 & 2284.4 \\
\hline 15 & 4.444 & 4.830 & 2283.9 \\
\hline 16 & 4.418 & 4.848 & 2286.0 \\
\hline 17 & 4.212 & 4.963 & 2288.6 \\
\hline 18 & 4.463 & 4.823 & 2284.9 \\
\hline 19 & 4.440 & 4.832 & 2283.9 \\
\hline 20 & 4.312 & 4.903 & 2286.5 \\
\hline 21 & 4.450 & 4.829 & 2284.9 \\
\hline 22 & 4.458 & 4.825 & 2284.9 \\
\hline 23 & 4.427 & 4.843 & 2285.8 \\
\hline & & & $2284.5 \pm 1.4(23)$ \\
\hline
\end{tabular}

Precision on alkalinity $=1.412284 .5=0.06 \%$.

For every sample, $\mathrm{S}=34.64, \mathrm{pH}_{\mathrm{i}}=8.148$ at $17.6^{\circ} \mathrm{C}\left(\mathrm{pH}_{16}=8.182\right), \mathrm{W}=255.9 \mathrm{~g} . \mathrm{N}_{\mathrm{HCI}}$. $0.1209 \mathrm{M}$.

TABLE III 
Experiments carried out (21 days after the experiment described in Table II) to determine the reproducibility of the proposed method

\begin{tabular}{|l|l|l|l|}
\hline Exp. & $\mathrm{pH}_{\mathrm{f}}$ & $\mathrm{V}_{\mathrm{HCI}}$ & $\mathrm{A}$ \\
\hline 1 & 4.416 & 4.848 & 2285.8 \\
\hline 2 & 4.386 & 4.863 & 2285.7 \\
\hline 3 & 4.416 & 4.850 & 2286.7 \\
\hline 4 & 4.412 & 4.850 & 2285.8 \\
\hline 5 & 4.381 & 4.868 & 2286.9 \\
\hline 6 & 4.423 & 4.847 & 2287.0 \\
\hline 7 & 4.418 & 4.855 & 2289.6 \\
\hline 8 & 4.318 & 4.900 & 2286.6 \\
\hline 9 & 4.415 & 4.845 & 2284.1 \\
\hline 10 & 4.417 & 4.848 & 2286.0 \\
\hline 11 & 4.302 & 4.903 & 2284.0 \\
\hline & & & $2286.2 \pm 1.5(11)$ \\
\hline
\end{tabular}

Precision on alkalinity $=1.5 / 2286.2=0.07 \%$.

For every sample $\mathrm{S}=34.64, \mathrm{pH}_{\mathrm{i}}=8.168$ at $16.2^{\circ} \mathrm{C}\left(\mathrm{pH}_{15}=8.184\right)$ and $\mathrm{W}=255.9 . \mathrm{N}_{\mathrm{HCI}}$ $=0.1209 \mathrm{M}$. $\mathrm{V}_{\mathrm{HCI}}$ and $\mathrm{A}$ are expressed in $\mathrm{cm}^{3}$ and $\mu \mathrm{mol} \mathrm{kg}^{-1}$, respectively.

\section{TABLE IV}

Accuracy of method using various standard solutions. The alkalinity is expressed in $\mu \mathrm{mol} \mathrm{kg}{ }^{-1}$

\begin{tabular}{|l|l|l|l|l|}
\hline Standard & Number of analysis & Values & & Error (\%) \\
\hline & & Exp. & Theoretical & \\
\hline 1 & 4 & 4319 & 4319 & 0 \\
\hline 2 & 4 & 4653 & 4660 & -0.15 \\
\hline 3 & 4 & 6822 & 6828 & -0.09 \\
\hline 4 & 5 & 2470 & 2470 & 0 \\
\hline 5 & 3 & 2454 & 2452 & 0.08 \\
\hline 6 & 6 & 2307 & 2308 & -0.04 \\
\hline
\end{tabular}


Influence of the directly measured parameter and constant used in the determination of the alkalinity and total inorganic carbon

\begin{tabular}{|c|c|c|c|}
\hline Parameter & $\begin{array}{l}\text { Assumed } \\
\text { error }\end{array}$ & $\begin{array}{l}\text { Consequent error in parameter } \\
\text { determined }\end{array}$ & \\
\hline & & $\% \mathrm{~A}$ & $\% \mathrm{C}_{\mathrm{T}}$ \\
\hline Titrant concentration & $0.1 \%$ & 0.1 & 0.1 \\
\hline $\begin{array}{l}\text { Mass or volume of the } \\
\text { sample }\end{array}$ & $0.01 \%$ & -0.01 & -0.01 \\
\hline Titrant volume & $0.02 \%$ & 0.02 & 0.02 \\
\hline Salinity & $0.003 \%$ & 0.0005 & 0.0023 \\
\hline Titration temperature & 0.1 & 0.005 & -0.005 \\
\hline $\mathrm{pH}_{\mathrm{i}}$ & 0.005 & 0.0025 & 0.02 \\
\hline $\mathrm{pH}_{\mathrm{f}}$ & 0.005 & -0.025 & 0.03 \\
\hline $\log \mathrm{f}_{\mathrm{H}}^{\mathrm{T}}$ & 0.010 & 0.05 & 0.06 \\
\hline $\log \mathrm{K}_{1}$ & 0.015 & 0.075 & 0.06 \\
\hline $\log \mathrm{K}_{2}$ & 0.03 & 0.015 & 0.25 \\
\hline $\log \mathrm{K}_{\mathrm{B}}^{\prime}$ & 0.03 & 0.015 & 0.12 \\
\hline $\log \mathrm{K}^{\prime} \mathrm{W}$ & 0.010 & 0.00005 & -0.002 \\
\hline $\begin{array}{l}\text { Neglecting } 1 \mu \mathrm{M} \\
\text { phosphate }\end{array}$ & & -0.0002 & $\begin{array}{l}+1 \\
\mu \mathrm{M}\end{array}$ \\
\hline Neglecting $20 \mu \mathrm{M}$ silicate & & 0.0001 & $\begin{array}{l}+1 \\
\mu \mathrm{M}\end{array}$ \\
\hline
\end{tabular}

Fig. 1. Differences (in $\mu \mathrm{molkg}{ }^{-1}$ ) at different salinities and temperatures, between alkalinity evaluated through the polynomial equation (expression 7) and the theoretical equation set (expressions 3-5), using $\mathrm{pH}_{\mathrm{i}}=8, \mathrm{pH}_{\mathrm{f}}=4.4, \mathrm{~N}_{\mathrm{HCl}}=0.1 \mathrm{M}$ and $\mathrm{Asp}=66$ $\mu \operatorname{molg}^{-1}$.

Fig. 2. Differences (in $\mu \mathrm{molkg}^{-1}$ ) at different initial and final $\mathrm{pH}$ between alkalinity evaluated through the polynomial equation (expression 7) and the theoretical equations (eqs. 3-5), using $\mathrm{t}=20^{\circ} \mathrm{C}, \mathrm{S}=35, \mathrm{~N}_{\mathrm{HCI}}=0.1 \mathrm{M}$ and $\mathrm{A}_{\mathrm{N}}=2000 \mu \mathrm{molkg}^{-1}$. 